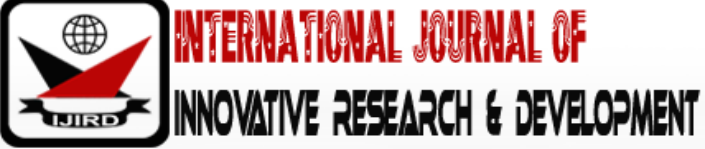

ISSN $2278-0211$ (Online)

\section{Effects of Teaching Work Load on Teacher Performance in Public Secondary Schools in Kitui County, Kenya}

Ndambo Stella Mang'uu
Ph.D. Candidate, Department of Curriculum, Instructional and Educational Management,
Maasai Mara University, Kenya
Dr. Maithya Paul
Lecturer, Department of Curriculum, Instructional and Educational Management,
Maasai Mara University, Kenya
Dr. Mwaura Kimani
Lecturer, Department of Educational Psychology \& Counselling,
Maasai Mara University, Kenya

\section{Abstract:}

School climate and teacher performance are critical factors in any learning institution that seeks to have competitive edge. Teachers from Kitui County have raised concern over unfavourable school climate that affects their performance. Despite the fact that some studies on school climate have been carried out in Kenya none of them has explored exhaustively on poor teacher performance. Hence there was need to carry out this study. The purpose of this study was to determine the effects of effects of teaching work load on teacher performance in public secondary schools in Kitui county. This study employed mixed methods approach and descriptive survey research design to reveal and measure the opinion of teachers and the indicators of school climate and was anchored on three motivational theories namely: McGregor theory $x$ and Maslow's Hierarchy of needs and Hertzberg's two factor theory. The study targeted 400 public secondary schools and 2417 teachers from Kitui county. Purposive and random sampling was used to select 40 principals and 488 teachers. Fractional method was used to sample 40 teachers from the 400-public secondary schools.20\% of 2417 teachers were randomly selected from each sub-county. Sample size for this study was calculated using hypergeometric formulae where 76 principals and 352 teachers were selected giving a total of 428 respondents. Data was collected using Questionnaires for teachers, interview schedules for principals and document analysis. Validity of the instrument was achieved by reading other research works, books and journals. Split half reliability was used to test teacher's questionnaire and principal's checklist. Research instruments were appraised through a pilot study on 25 teachers and 5 principals from Katulani sub-county. Data was analysed qualitatively and quantitatively using Pearson correlation moment to test the questionnaire, Analysis of variance (ANOVA) and multiple regression. Descriptive statistics and inferential statics were used. Descriptive statistics aided by statistical package for social sciences (SPSS) version 21.0 was used. Quantitative data was presented in percentages, $t$-test, frequencies and tables while qualitative data was organized into thematic categories according to the objectives of the study. The study established that there is statistical significant relationship between teaching workload and teacher performance $p$ value $=0.001<0.05$ level of significant.The study concluded that teachers felt they had a high teaching workload hence lacking ample time for lesson preparation and this made them feel they had prepared their students for assessment. The study recommended the need for school principals to balance teacher's workload for them to become productive by getting enough time for lesson preparation.

Keywords: Teaching work load, teacher performance, public secondary schools, school climate

\section{Introduction}

For many societies' world over, education has always been the key to a promising future. Any learning intuition needs to have a favourable working environment in order to achieve success. School climate is one of the elements that contribute widely towards teacher performance and student's achievement. Adeogun and Olisaemeka (2011), defines school climate as the total measure of school characteristics such as relationships between principals and teachers, students, parents, administrators as well as the physical facilities. However, the concern on the influence of school climate on teacher performance is a global issue that needs to be investigated. The World Bank (2017), indicated existence of a learning crisis in the low and middle - income countries where it revealed that schools put a lot of emphasis on schooling without focusing on student learning. United Nations Educational Scientific Cultural Organization (UNESCO) (2017), documented the SDGs 2016-2030 of which Goal no. 4 requires all nations to provide equitable and inclusive quality education and promote lifelong learning opportunities for all by 2030. The SDGs also require that every human being 
acquire twenty first century skills, knowledge, attitudes and values to deal with the challenges of the world and realize a sustainable future. This can only be achieved if schools adopted the right school climate. According to Organisation for Economic Co-operation and Development (OECD,2012) lifelong skills development will effectively address inequality, access to quality education, acquisition of essential skills for social development, labour market integration and youth unemployment challenge

Jepketer (2017), opines that the skills that will confront today's world challenges will depend on the improvement of students' performance with the teacher being part of the process or pathway to learning. The teacher can only play this role adequately if the school climate is appropriate and promotes student learning. Further, Global Monitoring Report (Burcu, Yeliz, Didem\&Ertugrul (2017), shows that Sub - Saharan Africa investment in education has not fully translated to development of functional skills and knowledge that could transform economies of which they live in general and individuals in particular. A good school climate promotes safety; healthy relationships, engaged learning and increased quality work. Teachers and principals are entrusted with the responsibility of ensuring quality performance of the students. Despite restricted resources a principal can find ways to improve teacher performance (Weathers, 2011). School climate is an important aspect in a school setting that influences internal and external environments including teacher performance and the overall student's achievement. School climate refers to the quality and character of school life. It is based on patterns of students, parents and school personnel experiences of school life that reflects norms, goals, values, interpersonal relationship, teaching, learning practices and organizational structures (Amrit, Cohen, Shawn \& Ann, 2013). School organizational structures include human resource, curriculum, communication, finance, discipline, record-keeping and guidance.

A study carried out in USA, on increasing staff morale in today's school with increased teacher responsibilities, high-stakes testing and decreased school funding (Hansen, 2016), recommended that schools needed to make an effort to increase staff performance since it affects the school in measurable ways including student performance on high-stakes testing and school climate. The study further noted that Principals are the primary members of the school community who have the ability to make lasting impacts to improve staff performance and added that they should support teachers, provide opportunities for teachers to build healthy relationships and provide them with autonomy. Another study carried out in Georgia State on components that contribute to adequate yearly progress in elementary schools by Angeline (2010), revealed that a teacher has the potential to impact a school ability to make adequate yearly progress and emphasized the need to increase teacher motivation in order to improve performance.

Another study on the impact of organizational climate on teacher's job performance by Selamat, Samsu and Kamalu (2013), revealed that organizational climate was a significant factor that could affect teachers' job performance. The aspect of principal's leadership behaviour was found to be critical in enhancing teachers' job performance positively or negatively. As part of a study of the impact of the AIDS epidemic on education in Botswana, Malawi and Uganda, representative groups of primary and secondary school teachers were asked if they agreed with the statement that 'teacher performance at their school was high'. From their responses it was concluded that performance in Botswana and Uganda was reasonably high whereas there appeared to be more cause for concern in Malawi, especially at primary schools where teacher performance was reported to be low Bennell and Swainson (2004).

Teacher performance also varies noticeably across schools in the same locations according to a small survey of secondary schools in Lusaka, Zambia. The breakdown of head teacher ratings of teacher performance was high at 44 per cent; moderate/average 22 per cent and poor at 33 per cent. Further the research showed that working with children was the main determinant of teacher job satisfaction. It is the rewarding nature of the job rather than pecuniary gain that is the primary motivation for becoming a teacher and concluded that teachers were most dissatisfied about work overload, poor pay and low status. It is believed that an educated person can easily realize better and more productive lives (Republic of Kenya, 2015).

From these studies it is evident that research on school climate and its influence on teacher performance have not been researched widely. Most of the studies cited on school climate are from foreign countries and very few have been carried out in Kenya especially Kitui County on the influence of school climate and teacher performance Teachers from Kitui county have raised some concerns on the challenges facing education especially in the secondary sector. Some of the critical issues mentioned were inadequate teaching and learning resources, high teaching workloads, poor principal's leadership behaviour and lack of teamwork. It was also reported that some teachers absented themselves from school while others reported to school late and drunk. Other teachers reluctantly attended to their classes and did not observe punctuality. As soon as the last bell for classes rang, some teachers hurriedly walked out of the school gate. Hence there was need to carry out this study and find out what promoted such behaviour and why teachers were not willing to stay within the school compound and carry out their duties and responsibilities This may fill the knowledge gap on how to improve teacher performance due to the increasing demand in quality education and the diminishing numbers of teachers in the country. It is important to create healthy school climate that influences teacher performance in order to retain teachers in their job. Some of the critical issues mentioned were inadequate teaching and learning resources, high teaching workloads, poor principal's leadership behaviour and lack of teamwork. This study sought to address the variable of school climate namely to examine the effects of teaching work load on teacher performance in public secondary schools in the study in order to fill the existing gap.

\section{Research Objective}

To examine the effects of teaching work load on teacher performance in public secondary schools in Kitui County. 


\section{Research Hypothesis}

There is no statistically significant relationship between teaching workload and teacher performance in public secondary schools in Kitui County

\section{Literature Review}

\subsection{School Climate}

School climate a critical element that contributes greatly towards the success of a school. It involves both internal and external environments which interact to create different types of school climates. In creating a healthy school climate, the principal plays a very vital role due to his/her management position in the school. According to Homana, Barber and Torney - Purta (2006), school climate refers to the quality and character of school life or the overall characteristics and atmosphere in the school. It is based on patterns and the safety of the school environment, experiences and principal's leadership practices (Adeyemi, 2004). Further, Getzel (2003), observed that teachers are important members of the school and play a pivotal role in educating the students. However, where the school climate becomes unfavourable, that is, where the school and physical environment are not safe, the principal's leadership is autocratic; this can affect teachers' job performance and students' learning outcomes.

Several types of school climates have been discussed below. The indicators of school climate are resources, teachers' workload, team building, principals' leadership behaviour, administrative support, communication, interpersonal relationships, and organizational structures for this study. Adeogun and Olisaemek (2011), conducted a study of 10 secondary schools in Lagos State of Nigeria to determine the relationship between school climate, student achievements as well as teacher productivity for sustainable development. Their study concluded that school climate can directly influence academic performance and teacher productivity. They also found that there was a significant relationship between school climate and performance hence the need to ensure positive school climate in order to have sustainable development. A study by Maxwell, Reynolds, Lee and Broomheat (2017), from Newcastle University in Australia on The Impact of School Climate and School Identification on Academic Achievement showed that students and members of staff have a significant impact on students' academic outcomes. The findings of the study indicated that student's perception of school climate significantly explain writing and numeracy achievement affected student's identification with the school; staff school identification did not play a significant role.

Even though a handful of researches have been done with regard to school climate (Hampden-Thomson and Galindo (2017), there's still lack of studies carried out concerning school climate and teacher performance especially in Kitui County.

\subsection{Teachers' Workload and Teacher Performance}

Teacher workload is an indicator of school climate that may influence teacher performance either positively or negatively. The Nova Scotia Teachers Union commissioned two researchers from St. Mary's University's Time Research Program (Andrew \& Jamie, 2000), to undertake a study of teacher workload and working conditions. These researchers collected data using a 24-hour time diary that was completed by 45.7 percent of the 1,800 teachers in the random sample of teachers. Supplementary questionnaires were also administered to assess teachers' perceptions of the changes in time required to complete certain teaching related functions, and to determine a teacher's degree of involvement with Individual Program Plans (IPP's) for special needs students; the amount of preparation time assigned to teachers within the instructional day and; a teacher's perception of how often he/she felt pressed for time.

Findings based on the time use diaries indicated that fulltime teachers in Nova Scotia spent an average of 52.5 hours per week on school related activities. Also, as a result of the combination of an intensification of teaching, insufficient preparation time within the instructional day (average of 179.9 minutes per 5-7-day cycle) and teachers' feelings that their work is not fully appreciated, stress levels are high among teachers. The authors also concluded that teachers do not have enough time for planning, reflection and collaboration with their peers and this affected their performance .Another study on The Elementary Teachers' Federation of Ontario (ETFO) Teacher Workload and Professionalism Study, Executive Summary Submitted to: Ontario Ministry of Education by Directions Evidence and Policy Research Group (2014), through the Interviews conducted with ETFO members indicated that workload is more a mental construct than a quantifiable entity. Teachers do not typically think of workload, unless the demands upon them become overwhelming, prompting them to regard the workload as 'too heavy.' This does not mean that workload has no external referents. Interviewees identified the following aspects of their work as frustrating or overwhelming: report card preparation, special education reporting, or preparing for a subject in the elementary curriculum (for example Art) for which they have had no formal preparation.

In addition to their instructional responsibilities, the average teacher responding to the survey spent 25 hours during the week most proximate to the survey administration on teaching related work, including 7 hours and 42 minutes planning and preparing lessons and nearly four additional hours assessing, correcting, evaluating or marking student work. According to the study the factors most frequently identified by interviewees as affecting teacher's workload were planning, marking and assessing, communication with parents and participation in extra-curricular programs. The number of students in a class, the range of their learning needs, and the number of identified special education students in the class, factors often referred to as class size and composition, were also perceived to affect teacher workload.Teacher's workload has direct impact on their performance as well as students' academic achievement. This means that overworked teachers are less likely to bring the energy, insights and resilience, positive and caring relationship that is effectively required in the classroom for teaching and learning to take place (Grenata, 2014). Further, Ayeni and Amanekwe 
(2018),found that high teacher's workload affects instructional task performance as well as student's academic performance. The study recommended that teachers should meet the workload standard for effective teaching and performance.

A study conducted by Melvina and Amalu (2013) on the impact of workload induced stress on the professional effectiveness of secondary school tutors in Cross River State showed that workload has no significant influence on seven dimensions (lesson presentation, use of instructional aids, evaluation of students, learning motivation, classroom management, supervision of co-curricular activities and personal/professional qualities) of professional effectiveness.

According to the World Health Organization (WHO) (2014), the overall well-being of teachers affects the school climate it noted that poor teacher's mental health is the major cause of early exits from the profession with up to quarter of new employees leaving within two years and third in a decade. The causes of stress include large classes, heavy workload, poor working relations with seniors, failure to understand and follow regulations, diverse learning needs of students and emotional disturbances arising from personal matters. Rose and Sika (2019), noted that teacher's performance is affected by the school climate especially when the teacher has a diminished mental wellbeing.

A study by Rose \&Sika (2019) on Determining Influence of Teachers Workload on Academic Performance in Secondary Schools Suba Sub County Kenya, revealed that influence of teacher's workload on academic performance was significant $(\mathrm{r}=.523, \mathrm{~N}=154, \mathrm{p}<0.01$ and that an additional unit increased teacher workload which resulted to a decrease in pupil academic achievement at .558 coefficient. The study concluded that it is important to reduce workload with tighter control in monitoring attendance to teachers in classroom. The study recommended that all stakeholders be involved in enhancing students' academic performance and the teachers to observe best practices in performing their duties. .According to Mutua (2019), in the daily nation (Wednesday 10 July, 2019) the roll out of the competency-based curriculum experts must ensure that teachers do not get burn out by heavy workload and other job-related factors. Potential triggers should be identified and corrective measures taken early. It was advised that teacher's mental well-being should be an integral part in the implementation of the new curriculum.

Teacher evaluation policy is the best vehicle to judge the quality and assuring that every classroom has a high qualified teacher. There is lack of teacher evaluation supervision by the principals. Darling-Hammond (2013), noted that the breakdown of teacher supervision and evaluation has provided insufficient feedback to teachers on their lesson delivery hence affecting both the teacher performance and student's achievement.

The curriculum-based establishment in Kenya requires every teacher in secondary school to teach a maximum of 28 lessons per week along other duties like marking continuous assessments for students, attending departmental meetings and talking to parents and participating in co-curricular activities (TSC County office Kitui 2019). A recent research in Kenya by the Saturday Standard (19 ${ }^{\text {th }}$ Sept. 2015) shows that Kenya has fewer teachers when compared to its peers in sub-Saharan Africa and they have an average of 25 pupils per teacher. In the year 2013, the Kenyan ratio 29:1 was also way above the UNESCO benchmark 17:1. In 2014 the growth rate for teachers went below that of pupil ratio and may become progressively worse due to increased number of retirees and natural attrition. Other teachers have moved to other ministries with better remuneration.

Most secondary schools have about eight departments namely Language (Kiswahili and English), science (Chemistry, Physics and Biology), Humanities (CRE, History and Geography), Technical (Business, computer and Agriculture) Games, Boarding and Counselling. In these departments a teacher is supposed to teach 27 lessons per week alongside other duties. Hence if a teacher leaves a certain department the workload goes up. This may result to low teacher morale since the teacher is overworked. Teachers are also entrusted with curriculum instruction, community relations, curriculum invention and innovation, reward strategy and motivation, setting up school organizational goals, objectives, and mission and vision statements and also coining the school motto. The other roles include; assessment and feedback, students' discipline, guiding and counselling among others (Fuller, Hollingworth and Young (2015). Poor teacher performance can be costly to an organization. Metin (2013), revealed that low morale can gradually destroy teachers' commitment and adversely affect productivity or the service delivery and alienate those they are supposed to serve (students). Hence there is need to carry out this study to find out whether high workload on secondary school teachers affect their performance.

\section{Research Methodology}

This study employed mixed methods approach and descriptive survey research design. The study targeted 400 public secondary schools and 2417 teachers from Kitui County. Purposive and random sampling was used to select 40 principals and 488 teachers. Fractional method was used to sample 40 teachers from the 400-public secondary schools. $20 \%$ of 2417 teachers were randomly selected from each sub- county. Sample size for this study was calculated using hypergeometric formulae where 76 principals and 352 teachers were selected giving a total of 428 respondents. Data was collected using Questionnaires for teachers, interview schedules for principals and document analysis. Validity of the instrument was achieved by reading other research works, books and journals. Split half reliability was used to test teacher's questionnaire and principal's checklist. Research instruments were appraised through a pilot study on 25 teachers and 5 principals from Katulani sub-county. Data was analysed qualitatively and quantitatively using Pearson correlation moment to test the questionnaire, Analysis of variance (ANOVA) and multiple regression. Descriptive statistics and inferential statics were used. Descriptive statistics aided by statistical package for social sciences (SPSS) version 21.0 was used. Quantitative data was presented in percentages, t-test, frequencies and tables while qualitative data was organized into thematic categories according to the objectives of the study. 


\section{Results and Discussion}

\subsection{Effects of Workload on Teacher Performance}

The study set out to examine the effects of teacher's work load on teacher performance in public secondary schools in Kitui County. Teacher's workload is an important feature on school climate that may influence teachers' performance either positively or negatively. The teachers were given several statements to respond to in relation to their workload in the school environment. The responses would lead the study to examine whether there was a relationship between the teacher's workload and their performance. The results are as shown in Table 1.

\begin{tabular}{|c|c|c|c|c|c|c|}
\hline & BASE & $\begin{array}{c}\text { Strongly } \\
\text { Agree }\end{array}$ & Agree & Neutral & Disagree & $\begin{array}{l}\text { Strongly } \\
\text { Disagree }\end{array}$ \\
\hline $\begin{array}{c}\text { Teachers have high teaching } \\
\text { workload }\end{array}$ & $\begin{array}{c}342 \\
100 \%\end{array}$ & $\begin{array}{c}216 \\
63.15 \%\end{array}$ & $\begin{array}{c}67 \\
19.59 \%\end{array}$ & $\begin{array}{c}12 \\
3.50 \%\end{array}$ & $\begin{array}{c}43 \\
12.57 \%\end{array}$ & $\begin{array}{c}4 \\
1.16 \%\end{array}$ \\
\hline $\begin{array}{l}\text { No ample time for lessons } \\
\text { preparations }\end{array}$ & $\begin{array}{c}342 \\
100 \%\end{array}$ & $\begin{array}{c}69 \\
20.17 \%\end{array}$ & $\begin{array}{c}173 \\
50.58 \%\end{array}$ & $\begin{array}{c}17 \\
4.97 \%\end{array}$ & $\begin{array}{c}82 \\
23.97 \% \\
\end{array}$ & $\begin{array}{c}1 \\
0.29 \%\end{array}$ \\
\hline $\begin{array}{l}\text { Have ample time to prepare } \\
\text { students assessments }\end{array}$ & $\begin{array}{c}342 \\
100 \%\end{array}$ & $\begin{array}{c}53 \\
15.49 \%\end{array}$ & $\begin{array}{c}84 \\
24.56 \%\end{array}$ & $\begin{array}{c}05 \\
1.46 \%\end{array}$ & $\begin{array}{l}171 \\
50 \%\end{array}$ & $\begin{array}{c}29 \\
8.47 \%\end{array}$ \\
\hline $\begin{array}{l}\text { Adequate time is provided for } \\
\text { marking assessments }\end{array}$ & $\begin{array}{c}342 \\
100 \%\end{array}$ & $\begin{array}{c}88 \\
25.73 \% \\
\end{array}$ & $\begin{array}{c}74 \\
21.63 \% \\
\end{array}$ & $\begin{array}{c}27 \\
7.89 \%\end{array}$ & $\begin{array}{c}99 \\
28.94 \%\end{array}$ & $\begin{array}{c}54 \\
15.78 \%\end{array}$ \\
\hline $\begin{array}{l}\text { Teachers carry out student's role } \\
\text { modelling effectively }\end{array}$ & $\begin{array}{c}342 \\
100 \%\end{array}$ & $\begin{array}{c}90 \\
26.31 \%\end{array}$ & $\begin{array}{c}241 \\
70.46 \%\end{array}$ & $\begin{array}{c}11 \\
3.21 \%\end{array}$ & $\begin{array}{c}0 \\
0 \% \\
0 \%\end{array}$ & $\begin{array}{c}0 \\
0 \% \\
0 \%\end{array}$ \\
\hline $\begin{array}{l}\text { Follow syllabus to prepare their } \\
\text { schemes of work }\end{array}$ & $\begin{array}{c}342 \\
100 \%\end{array}$ & $\begin{array}{c}144 \\
42.10 \%\end{array}$ & $\begin{array}{c}122 \\
35.67 \%\end{array}$ & $\begin{array}{c}04 \\
1.16 \%\end{array}$ & $\begin{array}{c}72 \\
21.05 \%\end{array}$ & $\begin{array}{c}0 \\
0 \%\end{array}$ \\
\hline $\begin{array}{l}\text { Some teachers involved in drug } \\
\text { and substance abuse due to work } \\
\text { related stress }\end{array}$ & $\begin{array}{c}342 \\
100 \%\end{array}$ & $\begin{array}{c}80 \\
23.39 \%\end{array}$ & $\begin{array}{c}142 \\
41.52 \%\end{array}$ & $\begin{array}{c}08 \\
2.33 \%\end{array}$ & $\begin{array}{c}70 \\
20.46 \%\end{array}$ & $\begin{array}{c}42 \\
12.28 \%\end{array}$ \\
\hline
\end{tabular}

Table 1: Effects of Workload on Teacher Performance

Out of the three hundred and forty-two (342) respondents who had returned their questionnaires, a majority of the respondents two hundred and eighty-three (283) representing $82.74 \%$ of the respondents agreed that teachers had a high teaching workload. Only forty-seven (47) respondents representing $13.73 \%$ of the teachers disputed the statement that teachers had a high workload while only 3.50\% remained neutral. The results are further shown in Figure 1.

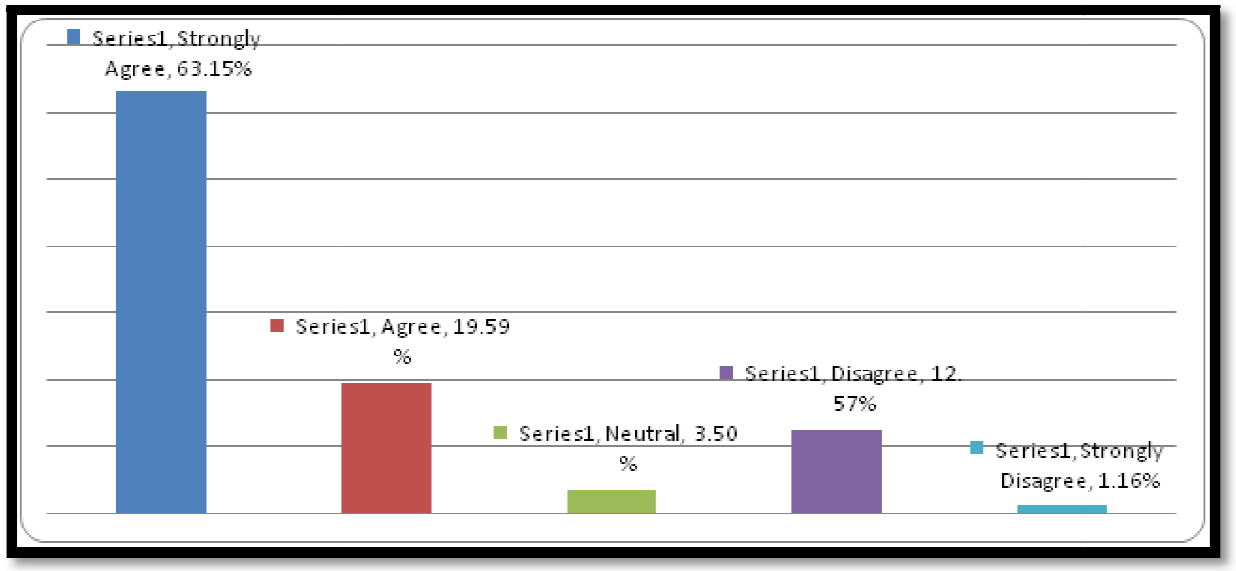

Figure 1: Teachers Have a High Teaching Workload

This means that teachers had a high workload. When teaching workload is high then teacher's performance may be adversely affected. The teaching workload could be attributed to teaching activities involved, which may entail both curricular as well as co -curricular. The observation schedule shows that the block timetable indicated majority of the teachers had more than 30 lessons weekly as well as other tasks. This is higher than the recommended 27 lessons per week alongside other duties. This may also have an effect on teacher's performance. The results agree with those of Ayeni and Amanekwe (2018), who reported that the teaching activities may increase teacher's workload and may have a negative impact on teachers' performance. The findings also concur with those of Tancinco (2016), who noted that teaching load had a negative effect on teachers' performance. The study went further to ascertain whether teachers had adequate time for lesson preparation. The results are shown in Figure 2. 


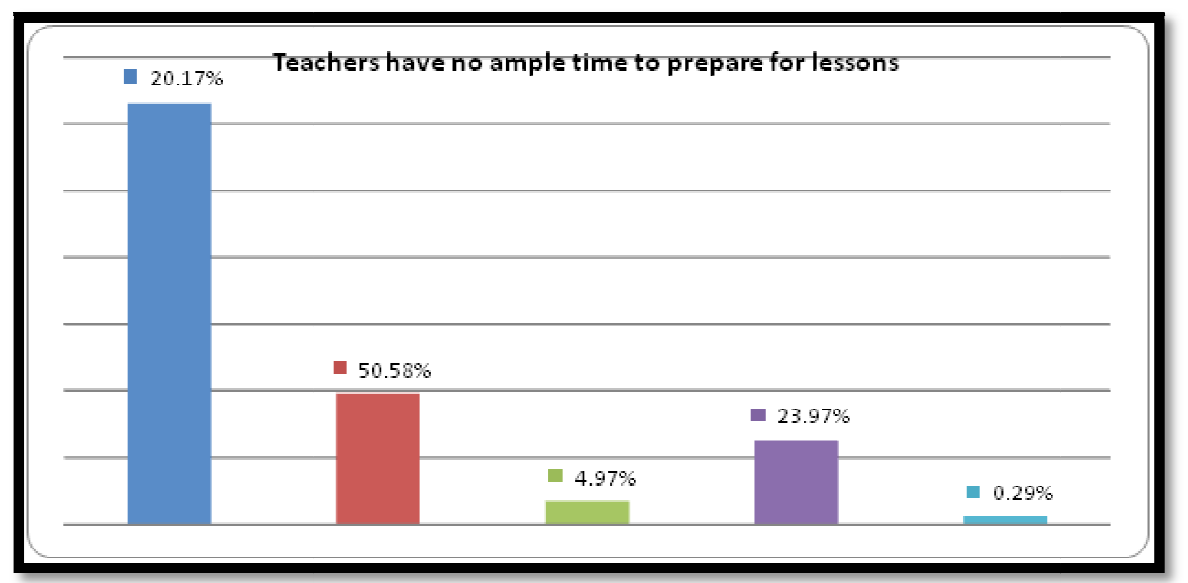

Figure 2: Teachers Have No Ample Time for Lesson Preparation

The results indicate that about seventy-one percent (70.75\%) of teachers agree that there was no ample time for lesson preparation while twenty-four percent (24\%) said they had ample time for lesson preparation and five percent (5\%) remained neutral. This implies that teachers are overloaded with duties and responsibilities as well a high teaching workload this affected their time for lesson preparation. The researcher observes that lack of ample time to prepare for lessons may have an impact on both students' achievement as well as the teacher's performance. These results corroborate the principals' response where eighty percent $(80 \%)$ of the principals agreed that the teachers were overloaded with instructional and non-instructional tasks hence this affected their performance. The principals further disagree (68\%) that teachers had sufficient daily planning time. This implies that teachers did not have enough time to prepare for the lessons due to high workload. The results agree with Tancinco (2016), who reported that teacher preoccupation with other responsibilities within the school setup could have an effect on their performance as well as their lesson preparation.

The study further set out to establish whether there was time to prepare students for assessment. Fifty-one percent (51\%) disagreed to the fact that they had time to prepare students assessment while thirty-four percent (34) indicated that adequate time was provided for marking assessments. This is further illustrated in the Figure 3.

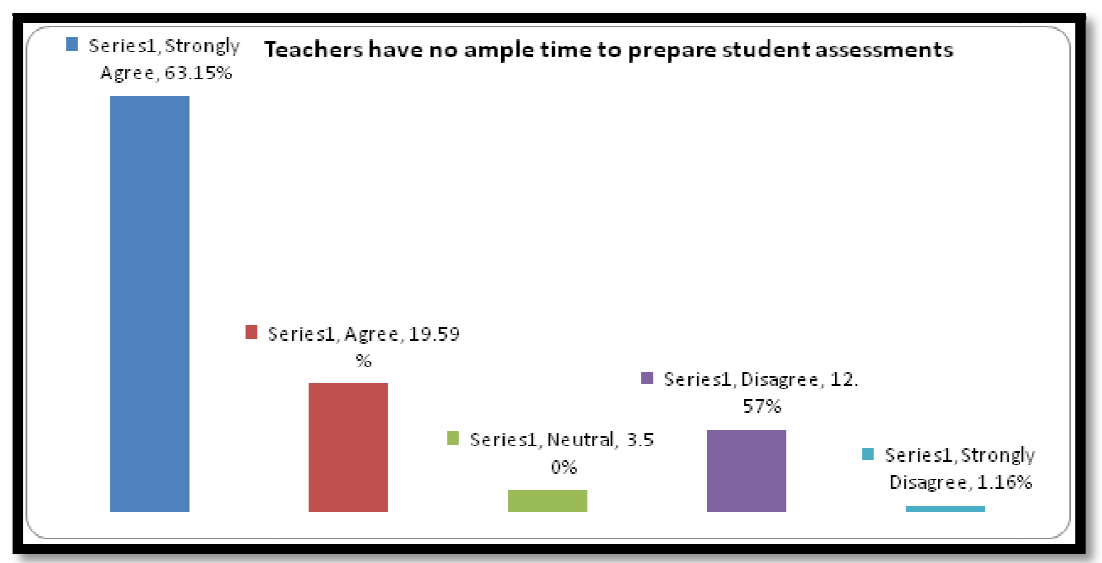

Figure 3: Teachers Have No Ample Time to Prepare Student Assessments

This implies that the high workload could not allow teachers to have time to prepare student assessments. The study therefore found out that there was no sufficient time for teachers to prepare student assessments.

\subsection{Teachers Have Adequate Time to Mark Student Assessments}

On the other hand, the 62 percent of the principals disagree that teachers marking and correcting students work took a lot of time since there was a set time for the same. The results from Metin (2013) agree with the findings of this study since teachers lack sufficient time for preparation of students for assessment. He noted that the classes were overcrowded, a lot of paper work and insufficient learning environment hence making it difficult for teachers to have ample time to mark students' assessments. 


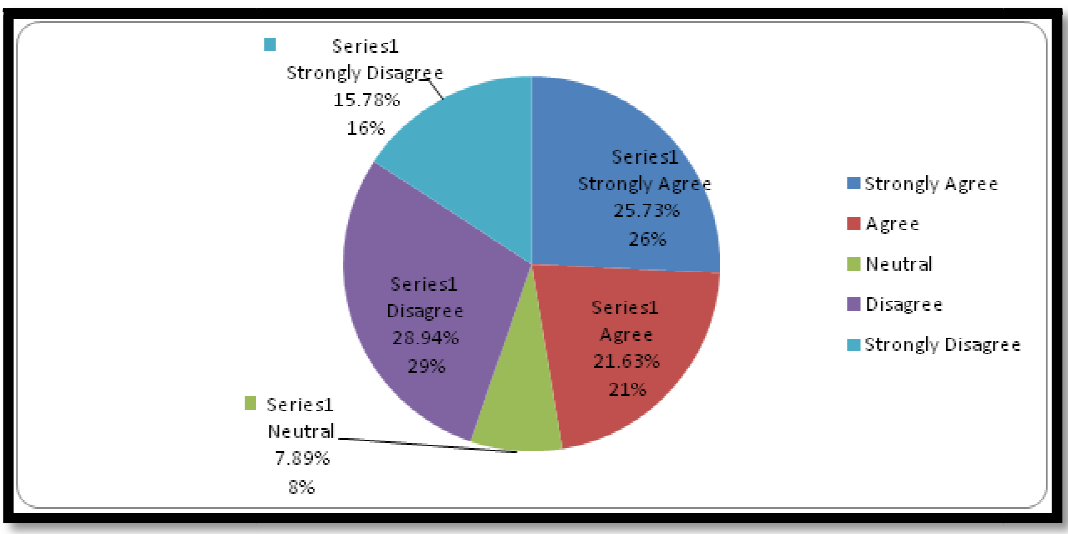

Figure 4: Teachers Have Adequate Time to Mark Student Assessments

Further, the study went ahead to find out whether teachers carried out student's role modelling effectively as this could be an indicator of a teacher's performance. The results are shown in Figure 5.

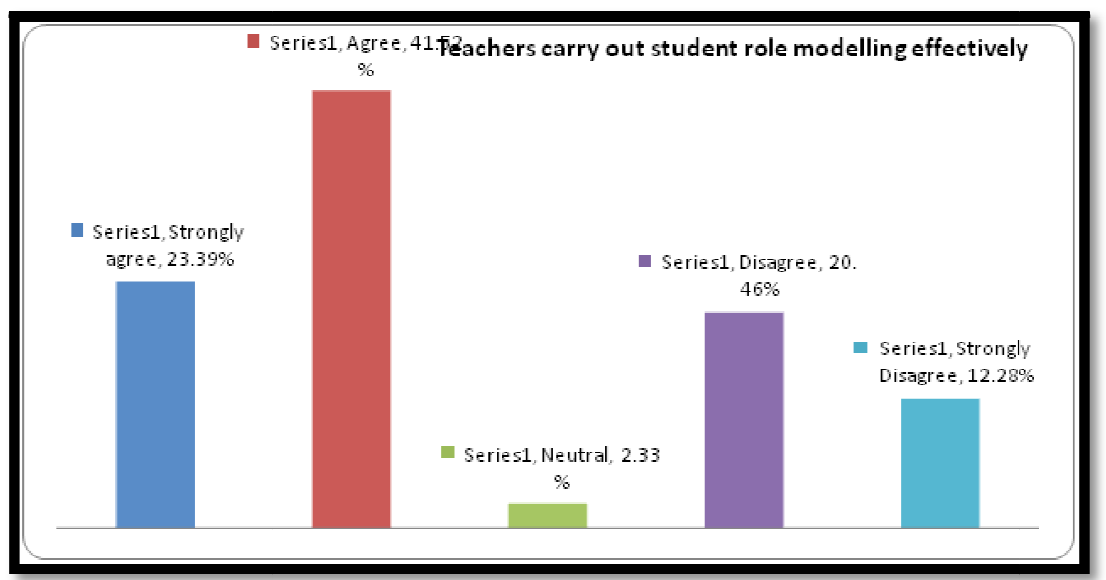

Figure 5: Teachers Carry out Student Role of Modelling Effectively

Study findings show that majority of the respondents (64.91\%) agreed that teachers carried out student role modelling effectively while $32.74 \%$ disagreed and only $2.33 \%$ remained neutral. This means that teachers carried out student role modelling effectively. This means that teachers carried out student role modelling effectively. However, this may be contradictory to earlier findings which indicated that teachers were overloaded and did not have adequate time to perform other tasks such as student role modelling.

\subsection{Some Teachers Were Involved In Drug And Substance Abuse}

The study went on to find out whether some teachers were involved in drug and substance abuse as this could be an indicator of a poor school climate, which in turn affects teachers' performance. The findings of the study are shown in Figure 6.

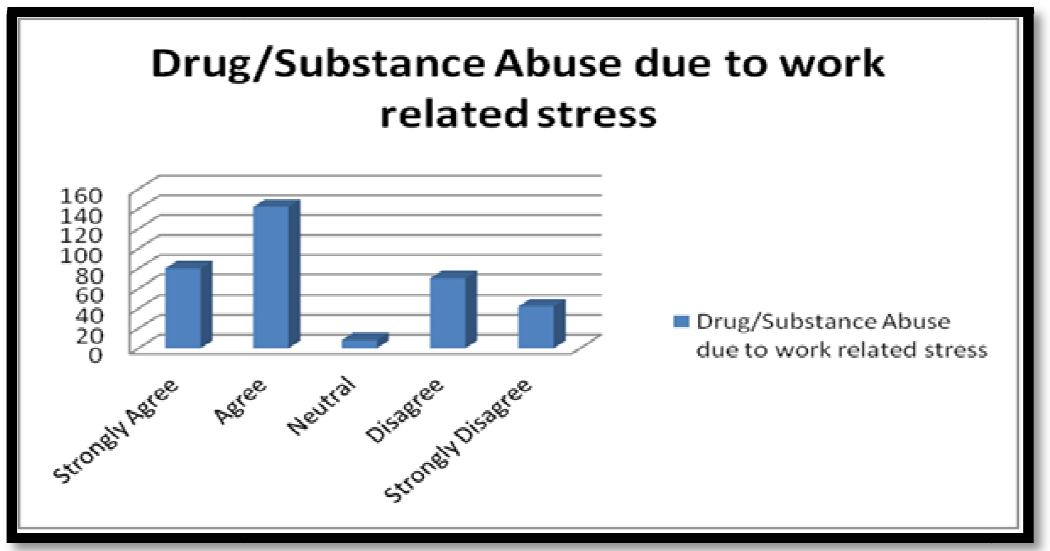

Figure 6: Some Teachers Are Involved in Drug and Substance Abuse Due to Work Related Stress

The results show that over sixty-four percent (64\%) of the respondents were in agreement that some teachers were involved in drug and substance abuse due to work related stress while slightly over thirty-two percent (32.74\%) disagreed. This means that many of the teachers were undergoing work related stress. These results corroborate with 
those of Rose and Sika (2019), who reported that teacher's performance is affected by the school climate especially when the teacher has a weakened mental wellbeing.

Wareng (2018), also noted that teacher's workload plays a significant role on their emotional exhaustion. It is worth noting that a majority of teachers have gotten into the norm of abusing drugs and substances. This may have a negative impact on the students especially those already who have unlearnt the behaviour of using drugs. The results concur with WHO on well- being of teachers affects the school climate as a result of teacher poor mental health hence encouraging an early exit from the profession.

The results of the study as shown in Table 2 shows that mentorship of students was effectively done as seventyfour percent agreed. This implies majority of the students admired the role modelling of the teachers' character. This was also supported by eighty percent $(80 \%)$ of the principals who noted that life skills were imparted on the students. The results concur with those of Bizmana (2014), who noted that role modelling traits shown by the teacher to the student such as praising students, display of patience, empathizing with students and listening had positive response and this was a moral lesson for the student in school. These studies observed that teachers were role models and mentorship may encourage self-esteem, empathy and moral reasoning, interpersonal communication and conflict resolution skills may be emulated by the students.

\subsection{Lesson Planning or Preparation, Presentation, Examination Feedback and Evaluation of Teaching on Teacher's Performance}

The study sought to find out whether teachers were involved in lesson planning or preparation, presentation, examination feedback and evaluation of teaching as this was thought to influence teacher's performance. The variables: Lesson preparation/planning, Examination feedback, Lesson presentation and Evaluation of teaching were thought to increase teachers' workload and were rated as of either high, moderate or low workload areas. The results are as shown in Table 2.

\begin{tabular}{|c|c|c|c|}
\hline Variables & High & Moderate & Low \\
\hline Lesson preparation/planning & $129(37.5 \%)$ & $160(46.8 \%)$ & $53(15.9 \%)$ \\
\hline Examination feedback & $66(19.3 \%)$ & $109(31.8 \%)$ & $168(48.9 \%)$ \\
\hline Lesson presentation & $159(46.4 \%)$ & $92(26.8 \%)$ & $92(26.8 \%)$ \\
\hline Evaluation of teaching & $76(22.2 \%)$ & $91(26.6 \%)$ & $175(51.1 \%)$ \\
\hline
\end{tabular}

Table 2: Key Work Load Areas

The study established that, lesson preparation was moderately rated at (46.8\%) while lesson presentation had a high responses rate at 46.4 percent

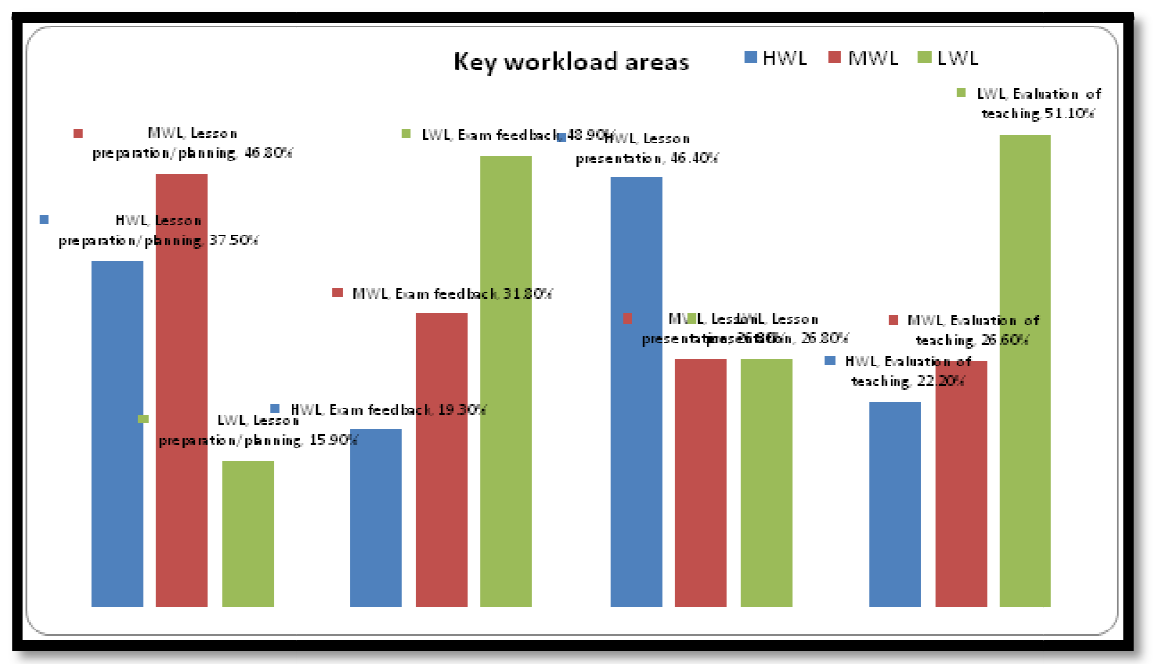

Figure 7: Key Workload Areas

Key: $H W L=$ High Workload $M W L=$ Moderate Workload $L W L=$ Low Workload

This implies that lesson planning and presentation required the teacher to have enough content and activities that would help the students learn and at least leave the class with an understanding. The results agree with Kimosop (2015), found that lesson planning is a critical part of teachers' instructional activities. A well-prepared lesson plan would help the teacher to systematically arrange, program and confidently present the lesson prepared. This is because the teacher is able to put into account and engage the learners to accomplish the intended learning objectives.

On the other hand, evaluation of teaching had no much load with 225 (51.1\%) of respondents stating it to be 'low'. This shows that schools need to review loading of teachers so that delivery could be normalized. The researcher observes the principals most times did not evaluate teacher teachings. This lack of teaching evaluation has affected teachers' performance since there is no one to give feedback to the teachers as they continue with their lessons. The results agree with those of Darling-Hammond (2013)who reported that the breakdown of teacher supervision and evaluation has 
provided insufficient feedback to teachers on their lesson delivery. The study sought to test the relationship between teachers' workload on teachers' performance.

\subsection{Extent to Which Teaching Workload Affects Teacher Performance}

The study used regression analysis to establish the relationship between the teaching workload and teacher's performance. The results are represented in the Model Summary, ANOVA table and the coefficient table herein.

\begin{tabular}{|c|c|c|c|c|}
\hline Model & R & R Square & Adjusted R Square & Std. Error of the Estimate \\
\hline 1 & $.373^{\mathrm{a}}$ & .139 & .121 & .446 \\
\hline
\end{tabular}

Table 3: Model Summary

a. Predictors: (Constant), some teachers involved in dug and substance abuse due to work related stresses, no ample time for lessons preparations, teachers have a high teaching workload, adequate time is provided for making assessments, have ample time to prepare student assessments, follow syllabus to prepare their schemes of work, teachers carry out students' role modelling effectively

\begin{tabular}{|c|c|c|c|c|c|c|}
\hline \multicolumn{2}{|c|}{ Model } & $\begin{array}{c}\text { Sum of } \\
\text { Squares }\end{array}$ & df & Mean Square & F & Sig. \\
\hline \multirow{2}{*}{1} & Regression & 10.772 & 7 & 1.539 & 7.728 & $.000^{\mathrm{b}}$ \\
\cline { 2 - 7 } & Residual & 66.514 & 334 & .199 & & \\
\cline { 2 - 7 } & Total & 77.287 & 341 & & & \\
\hline
\end{tabular}

Table 4: ANOVA ${ }^{a}$

a. Dependent Variable: Teacher's workload affects their performance

b. Predictors: (Constant), some teachers involved in dug and substance abuse due to work related stresses, no ample time for lessons preparations, teachers have a high teaching workload, adequate time is provided for making assessments, have ample time to prepare student assessments, follow syllabus to prepare their schemes of work, teachers carry out students' role modelling effectively

\begin{tabular}{|c|c|c|c|c|c|}
\hline \multirow[t]{2}{*}{ Model } & \multicolumn{2}{|c|}{$\begin{array}{l}\text { Unstandardized } \\
\text { Coefficients }\end{array}$} & \multirow{2}{*}{$\begin{array}{c}\text { Standardized } \\
\text { Coefficients } \\
\text { Beta }\end{array}$} & \multirow[t]{2}{*}{$\mathbf{t}$} & \multirow[t]{2}{*}{ Sig. } \\
\hline & B & Std. Error & & & \\
\hline (Constant) & .785 & .160 & & 4.895 & .000 \\
\hline $\begin{array}{l}\text { Teachers have a high teaching } \\
\text { workload }\end{array}$ & .027 & .023 & .072 & 1.198 & .232 \\
\hline $\begin{array}{l}\text { No ample time for lessons } \\
\text { preparations }\end{array}$ & -.015 & .030 & -.029 & -.506 & .613 \\
\hline $\begin{array}{l}\text { Have ample time to prepare student } \\
\text { assessments }\end{array}$ & .025 & .027 & .067 & .951 & .342 \\
\hline $\begin{array}{l}\text { Adequate time is provided for } \\
\text { marking assessments }\end{array}$ & .032 & .021 & .098 & 1.552 & .122 \\
\hline $\begin{array}{l}\text { Teachers carry out student's role } \\
\text { modelling effectively }\end{array}$ & -.158 & .037 & -.506 & -4.241 & .000 \\
\hline $\begin{array}{l}\text { Follow syllabus to prepare their } \\
\text { schemes of work }\end{array}$ & .066 & .034 & .211 & 1.950 & .052 \\
\hline $\begin{array}{c}\text { Some teachers involved in drug and } \\
\text { substance abuse due to work related } \\
\text { stresses }\end{array}$ & -.004 & .032 & -.014 & -.130 & .897 \\
\hline
\end{tabular}

Table 5: Coefficients ${ }^{a}$

Dependent Variable: Teacher's Workload Affects Their Performance

From the model table the $\mathrm{R}$ Squared shows that the model explains $13.9 \%$ of the dependent variable that is teacher's performance. The ANOVA shows the p-value $=0.001<0.05$ level of significance. The critical value of $F$ at 0.05 significance level with 7 and 334 degrees of freedom is at 2.70 less than the calculated $F$ value (7.728). With the degree of confidence being higher, then there is a significance relationship between the effects of teacher's workload on their performance. From the coefficient table the only significant variable is teachers carry out students' role modelling effectively at $p$-value $=0.001$. The other variables have been highly rated with some teachers are involved in drug and substance abuse due to work related stresses having a p-value $0.897>0.05$, followed by no ample time for lessons preparation at $p$-value $=0.613$ and teachers have ample time to prepare students for assessments at a $p$-value $=0.342$. The ANOVA shows the $\mathrm{p}$-value $=0.001<0.05$ level of significance. The critical value of $\mathrm{F}$ at 0.05 significance. This implies that there is statistically significant relationship between teaching workload and teacher performance 


\section{Conclusion}

The study concluded that teachers felt they had a high teaching workload hence lacking ample time for lesson preparation and this made them feel they had prepared their students for assessment.

\section{Recommendations}

There is need for school principals to balance teacher's workload for them to become productive by getting enough time for lesson preparation.There is need for the government and other stakeholders to employ more teachers to reduce teacher's workload for better performance to realized, this is because the teachers will be given enough time by the teachers during learning process as well as preparation for assessment.

\section{References}

i. Adeyemi, J. K. (2004). Resource situation and internal efficiency of Technical Colleges in Nigeria. PhD Thesis. University of Ibadan.

ii. Adeeogun, A.A. \&Olisaemeka, B.U.(2011). Influence of School Climate on students Achievement and Teachers Productivity for sustainable Development Online Submission,US-China Education Review v8 n4 p 552-557 April 2011

iii. Andrew,S.H.\& Jamie E.S. (2000). Life on and off the job.Atime-use study of Nova Scotia teachers.Time Use Research Program,Saint Marys University,Hlifax,Canada

iv. Amrit,T.,Cohen,J., Shawn, G.\& Ann, H.D. (2013). A Review of school climate Research ,Review of Educational Research 83(3) 357-385DOI:10:3102/0034654313483907

v. Akram, M. J. (2014). Factors affecting the performance of teachers at higher secondary level. Punjab. MED Thesis, Pir Mehr Ali Shah Arid Agriculture University.

vi. Angeline E. M. (2010) School climate components that contribute to Adequate yearly Progress in Elementary school, A Dissertation submitted to the graduate faculty of Georgia University, Statesboro, Georgia.

vii. Baregeya, J. (2009). Influence of Head teacher's general and Instructional supervisory Practice on teacher's work performance in Secondary Schools in Entebbe Municipality, Wakiso District, Uganda. Entebbe: Nkumba University.

viii. Bennell, P.S. \& Swainson, (2004). Teacher motivation and incentives in Sub-Saharan Africa\& Asia ,knowledge \& skills for development,Brighton

ix. Bizimana, B. (2014). Teaching and learning resources Availability and Teachers Effectiveclassroom Management and content delivery in secondary schools in HuyeDistrict,Rwanda.

x. Burcu M.A.,Yeliz, D., Didem, A. \& Ertugrul, P. (2017). Education Monitoring Report 20162017Doi:10:13140/RG:2,2 30397:56805

xi. Cohen, \& Geier, V. K. (2010) School climate research summary. Retrieved fromhttp://www.school climate.org/climate/school climatebriefs.php

xii. Cohen, J. (2012): school climate and culture improvement: A prosocial strategy that Recognizes educates and supports the whole child and the whole school community. In P.M Brown,M. W Corrigan \& Higgins' Alessandro (Eds). The Handbook of prosocial Education(pp.227-270). Blue Ridge summit, P.A: Rawman and Littlefield publishing group.

xiii. Darling-Hammond, L. (2013). Getting teacher evaluation right. New York, NY: TeachersCollege Press.

xiv. UNESCO (2017) Education for sustainable development Goals:Learning objectivesUNESCODivision for inclusion,Peace and sustainable development,Education sector,Paris,France

xV. Fuller, E.J., Hollingworth,L.\&Young,M.D.(2015). Working conditions and retention of principals insmall and mid-sized urban districts in soutyherland I,E,Sanco K,L,Scriber,J,P(Eds) Leading Small and Mid

xvi. Getzel, J. W. (2003). Social behaviour and the administrative process. Journal of Review 65 (2),315 - 373

xvii. Ghavifekr, S. \&Rosdy, W.A.W. (2015). Teaching and learning with technology: Effectivenessof ICT integration in schools. International Journal of Research in Education and Science (IJRES), 1(2), 175-191.

xviii. Hansen, K. M. (2016). Effective school Leadership Practices inSchools with Positive climates in the Age of HIGH -Stakes Teacher Evaluations. All NMU Masters theses 125 https// commons.nmu.edu/theses/125

xix. Hmpden-Thomson G., \&Galindo, C.(2017). Family relationships,school satisfaction and theAcademic achievement of young people,Educ,Rev.69 248-265 doi.10.1080/001319112016.1207613

xx. Homana, G., Barber, C. \& Torney - Purta, J. (2006). School citizenship education climate assessment. New York: National Center for learning and citizenship Press.

xxi. Kimosop, E. (2015). Teacher preparedness for effective classroom instruction of the secondary school Christian Religious Education curriculum in Kenya. International Journal of Scientific Research and Innovative Technology ISSN: 2313-3759 Vol. 2 No. 12; December 2015

xxii. Kurdziolek, M. A. (2011). Classroom resources and impact on learning Dissertation submitted to the faculty of the Virginia Polytechnic Institute and State University in Partial fulfilment of the requirements for the degree of Doctor of Philosophy in Computer Science Blacksburg, Virginia.

xxiii. Metin, M. (2013). Teachers' Difficulties in Preparation and Implementation of Performance Task. Journal of Educational Sciences: Theory and Practices 13(3). Educational consultancy and Research Centre. www.edam.com.tr/estpDOI:10.12738/estp.2013,2,1452.

xxiv. Melvina\&Amalu (2013) GLOBAL Journal of Education Research vol.13,2014:15-22 NigeriaISSN 1596-224 
xxv. Mutua Ezekiel(2019). Teachers burn out and Heavy workload, Daily NationNewspaper,Nairobi, Wednesday $10^{\text {th }}$ July,2019Nation media

xxvi. Neal, D. (2011). The design of performance pays in education in E.A Hanushek, S. Machin\&L.Woessman (EDS), Handbook of economics of Education Vol. A. Amsterdam

xxvii. Ngure, S. M. (2012). Impact of resource utilization in education as perceived by teachers in secondary schools in Mathioya Sub County, Muranga County, Kenya. Unpublished Thesis Kenyatta University

xxviii. OECD (2012). Equity and Quality in Education: Supporting Disadvantaged Students and Schools.OECD Publishing. (Online). Available at; http://www.oecd.org/edu/school/0293148.pdf. Retrieved; 19.03.2020.

xxix. Omondi, 0. (2010). Teaching/Learning Resources and Academic Performance inMathematics in Secondary Schools in Bondo District of Kenya. Kampala International University Kampala, Uganda Tel : 256-783-104-687 E-mail : yaraphilias@yahoo.com

xxx. Osarenren, R. I., Osaghae, \& Irabor, Q. O. (2012). Availability and Adequacy of Human and Material resources for the teaching and learning of skill-based courses in Nigeria Public Universities Department of Educational and management, Faculty of Education Alli University, P.M.B 14Ekpoma, Edo state, Nigeria.

xxxi. Pajares F. (2002). The Development of Education self efficacy; development of achievement of motivation (pp.15-32), San Diego. Academic Press: CA.

xxxii. Rochelle, J., Shechtman, N., Tatar, D., Hegedus, S., Hopkins, B., Empson, S., et al. (2010).

xxxiii. Integration of Technology, Curriculum, and Professional Development for Advancing Middle School Mathematics: Three Large-Scale Studies. AERJ, (Online First vs. June 2, 2010).

xxxiv. Republic of Kenya (2015). Ministry of Education science and Technology National Education

xxxv. Sector Vol.1 Basic Education programme Rtionale and A pproach 2013-2018

xxxvi. Republic of Kenya (2013). The Basic Education Act 2013, No.14 of 2013.Nairobi : Government Printers

xxxvii. Republic of Kenya (2011). Access and Quality in the Kenyan Education System. A review of the progress, challenges and potential solutions. Nairobi : Office of the Prime Minister of Kenya.

xxxviii. Rose A.\&Sika O. (2019). Determining influence of Teachers workload on Academic Performance in Secondary schools in Suba Sub-County,Kenya

xxxix. Selamat, N., Samsu, N. Z. \& Kamalu, N. S. (2013). The impact of organizationalclimate on Teacher's job performance faculty of education, university Technology, Mara, Shahlarm, Malaysia

xl. Stronge, J. and Tucker, P. (2005). Linking Teacher Evaluation and Student Learning. ASCD Learning. Retrieved on 19/3/2020 from http://www.edweek.org/ew/section/multimedia/teacher-performance-evaluationissue-overview.html

xli. Tancinco, N. P. (2016). Status of Teachers' Workload and Performance in State Universities of Eastern Visayas: Implications to Educational Management. IOSR Journal of Business and Management (IOSR-JBM) e-ISSN: 2278487X, p-ISSN: 2319-7668. Volume 18, Issue 6.Ver. IV (Jun. 2016), PP 46-57 www.iosrjournals.org

xlii. Weathers M (2011). Teacher community in urban elementary schools: the role of leadership and bureaucratic accountability. Education policy analysis Analysis, 19(3), 1-39. Retrieved from http://www.hwilson web.com.

xliii. Wentzel, K. and Watkins, D., (2002). Peer relationships and collaborative learning environment of teaching as contexts for academic enablers. School psychology Review, 31(3), 366 - 367

xliv. World Bank (2017). Education Global Practice Group Development Research GROUP AfricanRegion,Policy Research Working Paper 79556

xlv. World Health Organisation (WHO). (2014). Mental Health: a state of well-being, http://www.who.int/ features/fact files/mental health/en/ [accessed 03.01.2020] 